[Agr. Biol. Chem., Vol. 29, No. 8, p. 757 762, 1965]

\title{
Production of a New Acidic Polysaccharide, Succinoglucan by Alcaligenes faecalis var. myxogenes
}

\author{
By Tokuya Harada, Tadashi Yoshimura, Hidemasa Hidaka* \\ and Atsuo Koreeda \\ Institute of Scientific and Industrial Research, Osaka University, Sakai, Osaka \\ and *Matsutani Chemical Co., Ltd., Itami, Hyogo, Japan \\ Received March 19, 1965
}

\begin{abstract}
A slimy non-spore-forming bacterium strain 10C3 isolated from soil was motile with peritrichous flagella and named Alcaligenes faecalis var. myxogenes. Studies were made on the conditions necessary for maximal production of a new acidic succinoglucan polysaccharide by this strain in shaken cultures. Much production was observed with sucrose, glucose, xylose, galactose, cellobiose, maltose, fructose, mannose and rhamnose. The yield was greatest with sucrose and decreased in order with the above sugars from about 36 to 23 per cent. The most suitable medium contained 4 per cent sugar, 0.5 per cent yeast extract and one per cent calcium carbonate in tap water. The optimum temperature was $28^{\circ} \mathrm{C}$.
\end{abstract}

Strain 10C3 was isolated from soil and could grow on a synthetic medium contiaining 10 per cent ethylene glycol as the sole source of carbon. It was found to produce quite large amounts of exocellular polysaccharide under suitable conditions." ${ }^{1}$ Furthermore, perliminary studies showed that this polysaccharide contained about 10 per cent succinic acid. ${ }^{2)}$ It was named succinoglucan 10C3 and, because of its unusual chemical and physical properties, this microbial polymer seemed to have potential industrial value. In the work reported here, the name Alcaligenes faecalis var. myxogenes is proposed for strain 10C3 and studies on the production of the new microbial polysaccharide by this organism are made. Preliminary accounts of this work have already been reported. ${ }^{2}$ '

\section{MATERIALS AND METHODS}

\section{Morphology and physiology}

The organism was isolated from specimen of soil

1) T. Harada and T. Yoshimura, J. Ferment. Technol., 42, 615 (1964).

2) T. Harada and T. Yoshimura, Biochim. Biophy. Acta, 83, 374 (1964). obtained from a field near our Institute in Sakai-shi, Osaka. The identification of the organism was performed according to procedures given in the Manual of Microbiological Methods ${ }^{3}$ unless otherwise stated. Studies on electron microscopy were done as follows. Cultures used were twenty-four and forty-eight hours old grown on nutrient agar medium. Turbid suspensions were allowed to stand for about ten minutes and were then washed in distilled water to remove inorganic salts which otherwise interfere in shadowed preparations. A small drop of the turbid suspension of washed cells was placed upon a collodion film and shadowed with platinum-palladium $(80: 20)$ at an angle of $15^{\circ}$. The specimens were examined by a HU-11 electron microscope.

Isolation of exocellular polysaccharide and cells from culture media

Each $95 \mathrm{ml}$ of the medium in $500 \mathrm{ml}$ flask was inoculated with $5 \mathrm{ml}$ of the seed culture grown in the same medium. The culture was méchanically shaken at $32^{\circ} \mathrm{C}$ for five days unless otherwise stated. The culture broth became viscous. After heat treatment to coagulate protein the viscous culture liquor was centrifuged for 90 minutes at $60,000 \times \mathrm{g}$. Then the supernatant liquid was decanted. The polymer 3) Society of American Bacteriologists, "Manual of Microbiological Methods." McGraw-Hill Book Co., Inc., 1957. 
was obtained from it by adding 2 volumes of ethanol and the bulk of material was removed from the surface with a strainer. The remainder was separated by complete decantation. Then the agar-like polymer was thoroughly washed with a mixture of water and $95 \%$ ethanol $(1: 2)$, partially dehydrated with $95 \%$ ethanol and then dried in vacuo over $\mathrm{P}_{2} \mathrm{O}_{5}$.

The precipitate obtained from the viscous culture liquor by ultracentrifugation contains cells with or without residual calcium carbonate. This precipitate was suspeded in water and the calcium carbonate was removed by centrifugation for a few minutes at 1,000 r.p.m. The harvested cells were then washed twice with distilled water and dried to constant weight in a vacuum over at $90^{\circ} \mathrm{C}$.

\section{RESULTS AND DISCUSSION}

\section{Taxonomy}

Strain 10C3 was named Alcaligenes faecalis var. myxogenes according to the nomenclature in Bergey's Manual. ${ }^{4}$ Its taxonomic description was as follows.

The organism is a non-spore-forming gram- negative rod measuring 0.5 to 1.0 by 1.0 to 3.0 microns, occurring singly or in pairs and is motile with peritrichous flagella. Colonies on agar are circular, convex, smooth, glistening and translucent. Unshaken cultures become turbid with pellicle. Gelatin is not liquefied. Litmus milk becomes alkaline with no other detectable changes. Growth on potato is moist, brown and viscid. Indole and hydrogen sulphide are not formed. Urea is not hydrolyzed. Nitrates are reduced. The orgnism is aerobic. Neither acid nor gas is formed from a variety of sugars (e.g. glucose, fructose, galactose, mannose, xylose) in the ordinary carbohydrate-peptone-beef extract media. $^{3)}$ According to Hugh and Leifson's method, ${ }^{5)}$ trace amount of acid is aerobically (in the open tube) formed from glucose while neither acid nor gas is anaerobically (in the covered tube) formed from it. Ethylene glycol, 1,2-propylene glycol, glycerol, lactate, pyruvate, succinate, fumarate, malate, $\alpha$-ketoglutarate, and aspartate, in addition to a

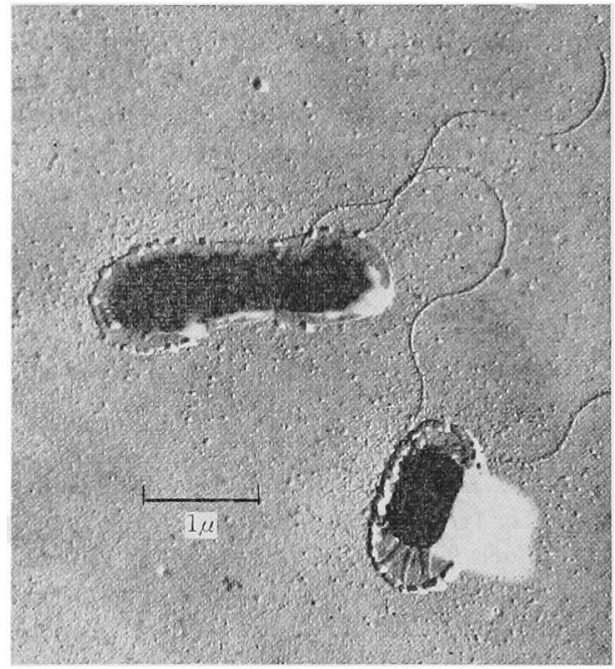

FIG. 1.

Explanation of Plate 1.

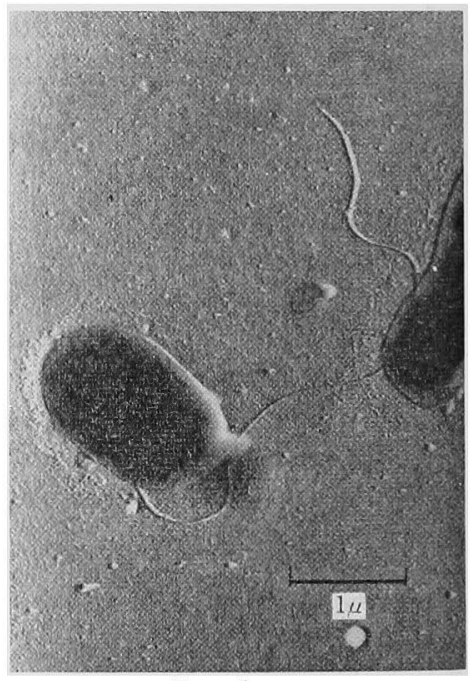

FIG. 2.

Electron micrograph showing peritrichous flagella (Fig. 1 from 24 hours, Fig. 2. from 48 hours old cultures) $\times 17,000$.

4) R. S. Breed, E. G. D. Murray and N. R. Smith, "Bergey's Manual of Determinative Bacteriology". The Williams and 5) R. Hugh and E. Leifson, J. Bact., 66, 24 (1953). 
variety of sugars, can be utilized as sole sources of carbon.

The exact position of the flagella is considered by many to be useful in bacterial classification. To clarify the site of the flagella in this organism, electron microscopic studies were made by one of us (A.K.). The organism showed lateral flagella (Figs. 1 and 2) and the number of flagellum was one, two or rarely many.

As shown in taxonomic description, the organism is gram-negative, non-spore-forming rod with peritrichous flagella and non-chromogenic on ordinary agar media. And also it makes litmus milk alkaline and does not form acid and gas in the ordinary carbohydratepeptone-beef extract media under unshaken cultures from sugars. These characteristics agree with those of the genus Alcaligenes. Vibrio alcaligenes cannot be distinguished from Alcaligenes faecalis without determining its type of flagellation. ${ }^{6)}$ It is generally agreed that the type species Alcaligenes faecalis is a peritrichous organism. It follows that any other flagellated species included in the genus must also be peritrichous. An organism resembling Alcaligenes viscolactis (viscosus), which is known to be non-motile and to produce ropiness in milk, produces levan-like polysaccharide. $^{7.81}$ Strain 10C3, as well as many other strains of the Alcaligenes type, can utilize ethylene glycol as the sole source of of carbon. ${ }^{12}$ On the other hand, all of strains of Pseudomonas and Achromobacter tested were shown to be unable to do so."

From these and other taxonomic descriptions, the organism may be referred to as Alcaligenes faecalis. In view of the production of a slimy polysaccharide, the organism was recognized as a variety of the species. Thus, the organism was named Alcaligenes faecalis var. myxogenes. Myxogenes is derived from Greek and has the literal meaning of slime produce.

\section{Production of polysaccharide}

Polysaccharide and cell production by strain $10 \mathrm{C} 3$ with several inorganic salts were tested in glucose-yeast extract medium (Table I). Yields of polysaccharide and cells in tap water were superior to those in distilled water. The yields of polysaccharide and cells with each of the inorganic salts tested were lower than those with tap water medium, except with $\mathrm{MnCl}_{2} \cdot 4 \mathrm{H}_{2} \mathrm{O}$ with which the yield of cells was the same as that with tap water medium. Addition of $\mathrm{K}_{2} \mathrm{HPO}_{4}$ did not increase the yields of polysaccharide and cells. Since it is likely that potassium and phosphate are? required in the metabolism of the organism, their requirements were evidently satisfied by the small amounts present in the yeast extract.

Table 1. Effects of Inorganic Salts and Tap Water on Polysaccharide and Cell Production in Glucose-yeast Extract Medium*

\begin{tabular}{|c|c|c|c|c|c|c|}
\hline \multirow{2}{*}{\multicolumn{3}{|c|}{ Distilled water }} & $\begin{array}{c}\text { Final } \\
\mathrm{pH}\end{array}$ & $\begin{array}{l}\text { Polysaccharide } \\
\text { produced } \\
\mathrm{mg} / 100 \mathrm{ml}\end{array}$ & $\begin{array}{c}\text { Dry weight of cells } \\
\text { produced } \\
\mathrm{mg} / 100 \mathrm{ml}\end{array}$ & $\begin{array}{l}\text { Polysaccharide/ } \\
\text { Dry weight of cells }\end{array}$ \\
\hline & & & 5.8 & 270 & 210 & 1.3 \\
\hline$n$ & $+\mathrm{K}_{2} \mathrm{HPO}_{4}$ & $100 \mathrm{mg}$ & 5.8 & 210 & 200 & 1.1 \\
\hline$n$ & $+\left(\mathrm{NH}_{4}\right)_{2} \mathrm{HPO}_{4}$ & $150 \mathrm{mg}$ & 6.0 & 190 & 240 & 0.8 \\
\hline$\pi$ & $+\mathrm{MgSO}_{4} \cdot 7 \mathrm{H}_{2} \mathrm{O}$ & $50 \mathrm{mg}$ & 5.8 & 250 & 250 & 1.0 \\
\hline$n$ & $+\mathrm{MnCl}_{2} \cdot 4 \mathrm{H}_{2} \mathrm{O}$ & $2 \mathrm{mg}$ & 5.7 & 240 & 280 & 0.9 \\
\hline$n$ & $+\mathrm{FeCl}_{3} \cdot 6 \mathrm{H}_{2} \mathrm{O}$ & $2 \mathrm{mg}$ & 6.0 & 360 & 250 & 1.4 \\
\hline Tap wat & & & 5.8 & 550 & 280 & 1.9 \\
\hline
\end{tabular}

* Basal medium: glucose $4 \%$, yeast extract (Wako) $0.5 \%$, pH 7.2 .

Incubation: 5 days at $32^{\circ} \mathrm{C}$.

6) F. Leifson, "Alcaligenes", p. 90. In "Atlas of bacterial flagellation". Academic Press. Inc., 1960.

7) C. Geiner and D. E. Wegemer, Appl, Microbiol., 2, 95

8) D. E. Wegemer and C. Geiner, Appl. Microbiol., 2, 97 (1954). (1954). 
The ratio of polysaccharide to cells was highest in tap water medium. Addition of $\mathrm{FeCl}_{3} \cdot 6 \mathrm{H}_{2} \mathrm{O}$ gave the highest yield of polysaccharide in distilled water medium. This suggests that one of the factors giving good polysaccharide production in tap water may be ferric ion. None of inorganic salts in glucose-yeast extract medium could not replace tap water completely in the production of polysaccharide. Thus, tap water was used in the culture medium in subsequent experiments. Table I shows also that a decrease of $\mathrm{pH}$ value occurred in all the culture media. This was due to the production of an acidic succinoglucan polysaccharide. None of the other acidic material could be detected in the culture filtrate by the usual method with paper chromatography. Since polysaccharide was scarcely formed and the decrease of $\mathrm{pH}$ value was very small in unshaken cultures as mentioned above, highly aerobic condition was found to be required for much production of acidic polysaccharide.
Table II shows the effect of calcium carbonate on the yields of polysaccharide and cells. Its addition greatly increased the yield of polysaccharide without affecting cell production appreciably. Calcium carbonate may favour polysaccharide production by neutralizing the acidic polysaccharide produced. Inorganic nitrogen was inferior to organic is nitrogen for polysaccharide production and it is generally known that organic nitrogen compounds are more suitable for polysaccharide production than inorganic nitrogen compounds. ${ }^{97}$

The effects of various crude nitrogen sources on the yieds of polysaccharide and cells are shown in Table III. Yeast extract (Wako) was the most suitable for polysaccharide production while polypeptone was extremely unfavorable for some unknown reason.

Various sugars were compared as carbon sources for polysaccharide cells production (Table IV). Good yields were observed with sucrose, glucose, xylose, galactose, cellobiose,

Table II. Effect of Calcium Carbonate on Polysaccharide and Cell Production in Glucose-yeast Extract Medium*

\begin{tabular}{|c|c|c|c|c|}
\hline & $\begin{array}{l}\text { Final } \\
\mathrm{pH}\end{array}$ & $\begin{array}{l}\text { Polysaccharide } \\
\text { produced } \\
\mathrm{mg} / 100 \mathrm{ml}\end{array}$ & $\begin{array}{c}\text { Dry weight of cells } \\
\text { produced } \\
\mathrm{mg} / 100 \mathrm{ml}\end{array}$ & $\begin{array}{l}\text { Polysaccharide/ } \\
\text { Dry weight of cells }\end{array}$ \\
\hline $4 \%$ glucose $+0.5 \%$ yeast extract (Wako) & 5.8 & 560 & 280 & 2.0 \\
\hline $\begin{array}{l}4 \% \text { glucose, } 0.5 \% \text { yeast extract }+1 \% \mathrm{CaCO}_{3} \\
(\text { Wako) }\end{array}$ & 6.4 & 1250 & 260 & 4.8 \\
\hline
\end{tabular}

TABLe III. EFfects of Grude Organic Nitrogen Sources on Polysaccharide and Cell Production*

\begin{tabular}{|c|c|c|c|c|}
\hline & $\frac{\text { Polysacchari }}{\mathrm{mg} / 100 \mathrm{ml}}$ & $\frac{\text { le produced }}{\text { yield }(\%)}$ & $\begin{array}{l}\text { Dry weight of cells produced } \\
\mathrm{mg} / 100 \mathrm{ml}\end{array}$ & $\begin{array}{l}\text { Polysaccharide/ } \\
\text { Dry weight of cells }\end{array}$ \\
\hline Yeast extract (Wako) & 1260 & 31.5 & 260 & 4.9 \\
\hline Bacto yeast extract (Difco) & 920 & 23.0 & 190 & 4.8 \\
\hline Corn steep liquor & 950 & 23.8 & 200 & 4.8 \\
\hline Bactopeptone (Difco) & 970 & 24.5 & 170 & 5.7 \\
\hline Polypeptone (Wako) & 260 & 6.5 & 180 & 1.3 \\
\hline
\end{tabular}

* Basal medium: glucose $4 \%$, nitrogen source $0.5 \%, \mathrm{CaCO}_{3} 1 \%$ in tap water. Incubation: 5 days at $32^{\circ} \mathrm{C}$.

9) R.F. Anderson, M.C. Cadmus, R.G. Benedict and M. F. Slodki, Arch. Biochem. Biophys., 89, 289 (1960). 
TABLE IV. COMPARISON OF VARIOUS SUGARS FOR POLYSACCHARIDE and Cell Production in Sugar-Yeast Extract Medium*

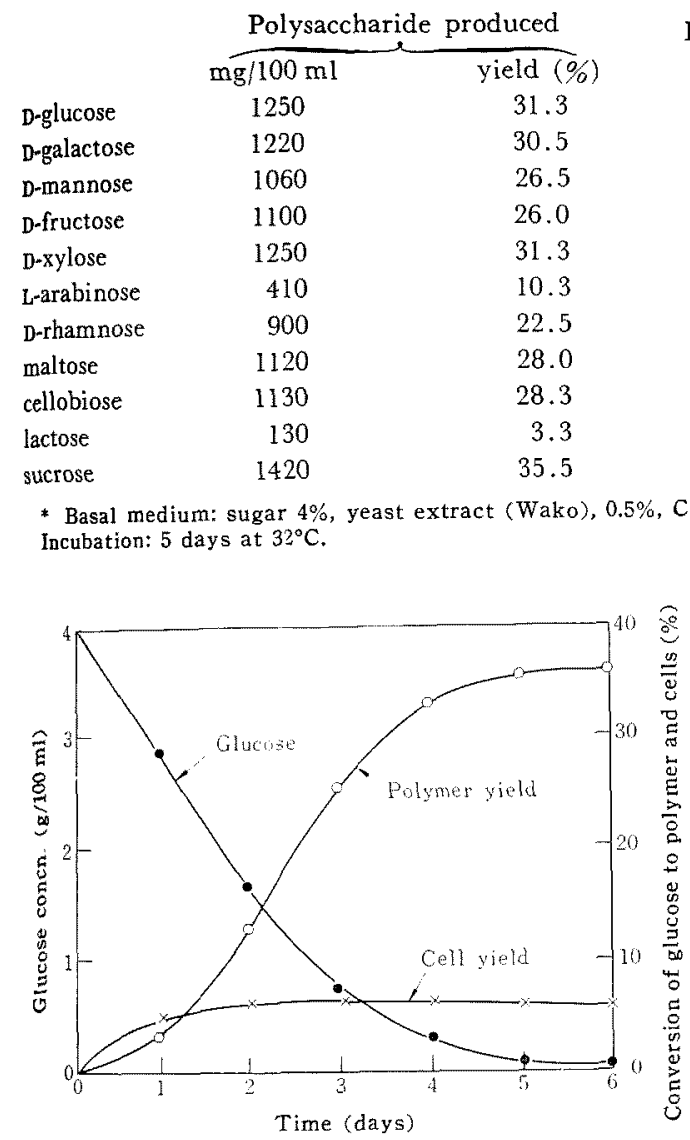

Frg. 3. Time Cource of Productions of Polysaccharide Containing Succinic Acid and Cells of Alcaligenes faecalis var. myxogenes, Stain 10C3. Incubation: 5 days at $32^{\circ} \mathrm{C}$.
Dry weight of cells produced $\mathrm{mg} / 100 \mathrm{ml}$

260
290
260
290
250
80
240
270
270
60
290

Polysaccharide/ Dry weight of cells
4.8
4.2
4.1
3.8
5.0
5.1
3.7
4.2
4.2
2.2
4.9

* Basal medium: sugar $4 \%$, yeast extract (Wako), $0.5 \%, \mathrm{CaCO}_{3} 1 \%$ in tap water.

Table V. Effect of Initial Glucose Concentration on Polysaccharide and Cellus Production in GLucose-Yeast extract Medium* $\begin{array}{cc}\text { Glucose added } & \text { Residual glucose } \\ \mathrm{g} / 100 \mathrm{ml} & \mathrm{g} / 100 \mathrm{ml}\end{array}$

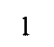

10

20

30

$4 \quad 0.25$

$5 \quad 1.37$

$6 \quad 2.95$
Polysaccharide produced Dry weight of cells produced $\overbrace{\mathrm{mg} / 100 \mathrm{ml}}^{\text {yield }(\%)}$

$\begin{array}{rrr}0 & 0\end{array}$

$\quad 570 \quad 28.5$

$920 \quad 30.7$

$1260 \quad 31.5$

$1140 \quad 22.8$

$870 \quad 14.5$

maltose, fructose, mannose and rhamnose. The yield was greatest with sucrose and decreased progressively in order to rhamnose with above sugars, varying from 35.5 to $22.5 \%$. The ratio of polymer to cell production was in the range of 5.0 to 3.7. Slight polymer production occurred with arabinose and lactose although the ratio of polymer to cells with arabinose was quite high. The time course of a typical fermentation in a shaking culture is shown in Fig. 3. The fermentation was essentially complete in five days. After this time, the polymer concentration did not increase appreciably, due to exhaustion of the added glucose. Maximal cell production was obtained in two days. With an initial glucose concentration of 2 to $3 \%$, its exhaus-

* Basal medium: yeast extract (Wako) $0.5 \%, \mathrm{CaCO}_{3} 1 \%$ in tap water. Incubation: 5 days at $32^{\circ} \mathrm{C}$. 
Table Vi. Effect of Temperature on Polysaccharide and Cell Production*

Temperature

Polysaccharide produced

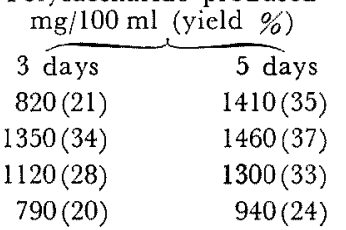

Dry weight of cells produced

$\begin{array}{cc}3 \text { days } & \mathrm{mg} / \mathrm{l} \text { days } \\ 180 & 260 \\ 240 & 260 \\ 260 & 270 \\ 200 & 260\end{array}$

Polysaccharide/ Dry weight of cells

$\begin{array}{cc}3 \text { days } & 5 \text { days } \\ 4.5 & 5.4 \\ 5.6 & 5.6 \\ 4.3 & 4.8 \\ 4.0 & 3.6\end{array}$

* Basal medium: glucose $4 \%$, yeast extract (Wako) $0.5 \%, \mathrm{CaCO}_{3} 1 \%$ in tap water.

tion was essentially complete in four days.

When the initial glucose concentration was increased from one to $6 \%$ (Table V), the concentration of polymer in the crude culture increased from one to $4 \%$ glucose concentration. A level of $4 \%$ gave the highest yield of polymer $(31.5 \%)$. Above this level, the residual glucose concentration was too high and the percentage conversion of glucose to polymer decreased sharply with increase in glucose concentration.

The effect of temperature on the yieds of polysaccharide and cells is shown in Table VI. The most suitable temperature for polysac- charide production was $28^{\circ} \mathrm{C}$. The final yields at incubation period of five days were almost the same at between $24^{\circ} \mathrm{C} \sim 32^{\circ} \mathrm{C}$ and lower at $36^{\circ} \mathrm{C}$. The optimum temperature for cell production was $32^{\circ} \mathrm{G}$. Therefore, the optimum temperature for polysaccharide production was rather low in comparison with that for cell production.

Acknowledgment This work was supported by a research grant of the Ministry of Education, Japan. The authors are indebted to Prof. Z. Nikuni and Dr. K. Komagata for their valuable suggestions. 